\title{
Review Article \\ Skewed Helper T-Cell Responses to IL-12 Family Cytokines Produced by Antigen-Presenting Cells and the Genetic Background in Behcet's Disease
}

\author{
Jun Shimizu, ${ }^{1}$ Fumio Kaneko, ${ }^{2}$ and Noboru Suzuki ${ }^{1}$ \\ ${ }^{1}$ Department of Immunology and Medicine, St. Marianna University School of Medicine, Sugao 2-16-1, Miyamae-ku, \\ Kawasaki 216-8511, Japan \\ ${ }^{2}$ Department of Dermatology, Fukushima Medical University School of Medicine, Fukushima 960-1295, Japan
}

Correspondence should be addressed to Jun Shimizu; jshimizu@marianna-u.ac.jp

Received 3 September 2013; Revised 12 November 2013; Accepted 27 November 2013

Academic Editor: Haner Direskeneli

Copyright (c) 2013 Jun Shimizu et al. This is an open access article distributed under the Creative Commons Attribution License, which permits unrestricted use, distribution, and reproduction in any medium, provided the original work is properly cited.

\begin{abstract}
Behcet's disease (BD) is a multisystemic inflammatory disease and is characterized by recurrent attacks on eyes, brain, skin, and gut. There is evidence that skewed T-cell responses contributed to its pathophysiology in patients with BD. Recently, we found that Th17 cells, a new helper $\mathrm{T}$ (Th) cell subset, were increased in patients with BD, and both Th type 1 (Th1) and Th17 cell differentiation signaling pathways were overactivated. Several researches revealed that genetic polymorphisms in Th1/Th17 cell differentiation signaling pathways were associated with the onset of BD. Here, we summarize current findings on the Th cell subsets, their contribution to the pathogenesis of $\mathrm{BD}$ and the genetic backgrounds, especially in view of IL-12 family cytokine production and pattern recognition receptors of macrophages/monocytes.
\end{abstract}

\section{Introduction}

Behcet's disease (BD) is a systemic inflammatory disease, characterized by recurrent signs and symptoms of oral aphthosis, genital ulcers, skin lesions, and uveitis. BD is not chronic inflammatory disease, but patients with BD suffer from recurrent attacks of acute and self-limiting inflammation. Repeated attacks of uveitis can lead to blindness.

The etiology of $\mathrm{BD}$ is largely unknown and skewed T-cell responses are associated with the development and maintenance of BD [1]. Excessive cytokine production by Th1 cells was reported using immunohistochemistry [2,3] and intracellular cytokine staining $[4,5]$. Thl dominance was observed in BD uveitis [6] and stomatitis as well [7]. We reported excessive Thl cell infiltration in BD skin and intestinal lesions but interleukin- (IL-) producing $\mathrm{T}$ cells were rarely detected [8-10]. T cells and peripheral blood mononuclear cells (PBMC) from patients with $\mathrm{BD}$ responded to KTH1 antigens of Streptococcus sanguinis in oral cavity of patients with $\mathrm{BD}$ and produced interferon $\gamma$ (IFN $\gamma$ ) and IL-12 [11].

Recently, Th1/Th2 paradigm was challenged by the discovery of various subsets of Th cells, such as Th17 cells and regulatory T (Treg) cells [12] (Figure 1). Researchers showed that Th cell differentiation in each subset was closely related and sometimes converted into another subset in response to environmental signals both in peripheral blood and in organs [13]. Recent studies on innate immune system suggested that antigen-presenting cells (APC) stimulated with patternrecognition receptors (PRR) and corresponding ligands regulated Th cell differentiation by cytokine production [14].

In this review, we summarize current understanding of Th cell responses to IL- 12 family cytokines produced by APC through PRR in patients with $\mathrm{BD}$. We also review recent findings on the disease susceptibility genes in $\mathrm{BD}$ and human autoimmune diseases, which regulate immune functions. 


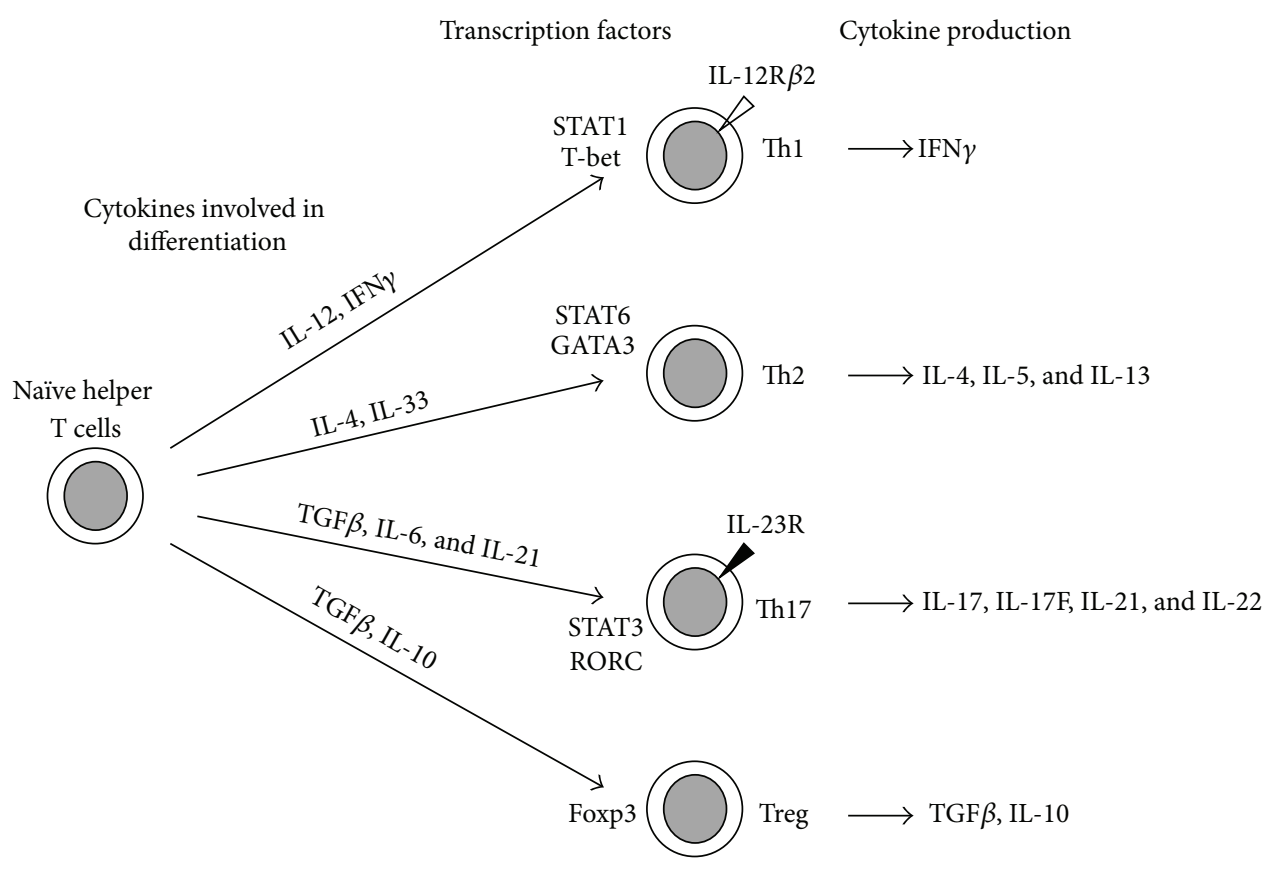

FIGURE 1: Current view of helper T (Th) cell subsets in humans [12]. Naïve Th cells differentiate into several Th cell subsets in the presence of appropriate cytokines. In response to the cytokines, the corresponding signaling molecules and transcription factors are expressed to regulate lineage commitments. Th1 and Th17 cells require IL-12 and IL-23 for their expansion, respectively. TGF $\beta$ : transforming growth factor $\beta$, STAT: signal transducer and activator of transcription 3, GATA: GATA transcription factor, RORC: retinoic-acid-receptor-related orphan receptor c, and Foxp3: forkhead box P3.

\section{Th1 Cells, Th17 Cells, Treg Cells, and IL-12 Family Cytokines}

Th17 cells produce a number of proinflammatory cytokines, including IL-17, IL-17F, IL-21 and IL-22. IL-6, IL-21, and transforming growth factor (TGF) $\beta$ were reported to play a role in the differentiation of Th17 cells which proliferated in the presence of IL-23 (Figure 1) [12]. Treg cells control T-cell immune responses and also need TGF $\beta$ for their differentiation (Figure 1) [12]. TGF $\beta$ activates Smad pathway and activated Smad protein leads to forkhead box P3 (Foxp3) expression which is a master gene of Treg cells [15]. In the presence of TGF $\beta$, IL-6/signal transducer and activator of transcription 3 (STAT3) signaling pathway plays a critical role in the induction of retinoic-acid-receptor-related orphan receptor $\mathrm{c}$ (RORC) expression which is a master gene of Th17 cells [16]. The two Th cell subsets require a common stimulation of TGF $\beta$ for the cell differentiation, but the resultant cells show opposite immune function in the presence or absence of IL-6.

As mentioned above, Th17 cells require IL-23 for the proliferation and survive, while Th1 cells require IL-12 for the differentiation (Figure 1). Recently, some researchers revealed that IL-12, IL-23, IL-27, and IL-35 are heterodimeric and share the subunits (Figure 2) and named them IL-12 family cytokines $[17,18]$. IL-23 is composed of p19 and p40 subunits, IL-12 is composed of p35 and p40 subunits, IL-27 is composed of p28 and Epstein-Barr-virus-induced gene 3 (Ebi3) subunits, and IL-35 is composed of p35 and Ebi3 subunits. The 4 cytokines require each corresponding receptor which also shares components for the function (Figure 2). For example, IL-12 receptor (IL-12R) and IL-23 receptor (IL-23R) share IL-12R $\beta 1$ subunit (IL-12R $\beta 1$ ), and IL-12R and IL-35R share IL-12R $\beta 2$ subunit (IL-12R $\beta 2$ ). It is thought that the 4 cytokines have overlapping but distinct effect on T cells with corresponding Janus kinase (JAK)-STAT signaling pathway. The experimental data demonstrated a functional spectrum from proinflammatory to inhibitory in Th cell differentiation (Figure 2). IL-12 and IL-23 are produced by activated dendritic cells and macrophages and induce inflammation through Th1 and Th17 differentiation, respectively. IL-23 phosphorylates STAT1, 3, 4, and 5, but STAT4 activation, which is essential to produce IFN $\gamma$, is not strong compared to that in IL-12 stimulation [19]. IL-27 is secreted from APC and produces IL-10 secreting Th cells through STAT1 and 3 phosphorylation [20]. IL-35 is mainly produced by Treg cells, amplifies IL-35-producing Th cells, and induces T-cell arrest through STAT1 and 4 heterodimer's in mice [21], but the function in humans is still controversial [22].

Moreover, IL-6 and IL-11, both of which being singlemolecule cytokines, need gp130 for their signal transductions in Th cell differentiation [23]. The concept of IL-12 family cytokine spectrum is simple, but physiological condition of the spectrum is supposed to be complicated. The relationship 
between the spectrum and TGF $\beta$ expression remains largely unclear.

\section{Th17 Cells, Treg Cells, and Tissue Damage}

Excessive expressions of Th17-related cytokines were found in psoriasis [26], rheumatoid arthritis [27], multiple sclerosis [28], and inflammatory bowel diseases [29]. Recently, several studies have demonstrated that Thl7 cell phenotype was not fixed in vitro and in vivo and Th17 cells turned into IFN $\gamma$ expressing Th17 cells and subsequently into nonstandard Th1 cells (Figure 3) [24, 25]. These two types of cells were thought to be more pathogenic and have higher affinity for inflammatory lesions than original Th17 cells [30-34]. IFN $\gamma$-expressing Th17 cells were found in several human autoimmune diseases such as Crohn's disease [30], psoriasis [31], multiple sclerosis [32], and juvenile idiopathic arthritis $[33,34]$.

Skewed Treg cell function was reported in many research articles of human autoimmune diseases [35]. Recent study revealed that there were differences in cell fate and functional stability between thymus-derived $(t)$ Treg cells and peripheryinduced (p)Treg cells [36]. tTreg cells had more effective functional stability, whereas pTreg cells were not stable in peripheral environment and converted into effector Th cells [37]. Epigenomic changes in Treg cells were suggested to regulate the Treg cell stability [38].

\section{Th17 and Treg Cell Involvement in BD}

It is generally thought that Th17 effector function is increased and Treg cell function is decreased in patients with BD. Overexpression of RORC mRNA [39, 40], underexpression of Foxp3 [41, 42], and high frequencies of Th17 cells [39-41, 43] were reported in patients with BD. Th17 cells were found in skin lesions $[39,40]$ and brain inflammatory lesions [41]. We recently reported that TGF $\beta /$ Smad signaling pathway of mononuclear cells was overactivated in patients with $\mathrm{BD}$ [44]. We also reported the possibility that Th cells in patients with BD showed higher sensitivity to IL-23 and IL-12, and produced more IFN $\gamma$ and IL-17, as compared with normal controls [40]. We observed Thl, Th17, and IFN $\gamma$-expressing Th17 cells simultaneously in one skin specimen obtained from erythema-nodosum-like lesion of BD (Figure 4). We speculate that both Th17 cells and Treg cells and the plasticity play a crucial role in the pathogenesis of $\mathrm{BD}$.

\section{Pathogen/Damage-Associated Molecular Patterns (PAMP/DAMP) and Toll-Like Receptors (TLR)}

Phagocytes were thought to be activated by various pathogens and pathogen-derived antigens in innate immune responses. Recent studies provided evidence for the existence of specific receptors on the phagocytes against the microbial antigens where they were named pattern-recognition receptors (PRR). The receptors are not rearranged even with adaptive immune system and recognize bacterial and viral pieces, known as pathogen-associated molecular patterns (PAMP). PAMP are indispensable parts of the microbes, such as lipopolysaccaride (LPS), peptidoglycan, bacterial DNA/heat shock proteins (HSP) and viral DNA/RNA [45]. Interaction between PRR and PAMP and subsequent induction of innate immune function are highly conserved among species [46]. Phagocytes with PRR recognition produced proinflammatory cytokines and upregulated major histocompatibility complex (MHC) proteins for the promotion of adaptive immune function [47].

Toll-like receptors (TLR) are transmembrane glycoproteins and called membrane-associated PRR. Ten functional human TLR have been identified [48]. TLR1, TLR2, TLR4, TLR5, and TLR6 were expressed on phagocyte cell surfaces and TLR3, TLR7, TLR8, and TLR9 localized within intracellular vesicles. It was shown that cell surface TLR recognized cell membrane-type PAMP, such as LPS and peptidoglycan, and intracellular TLR recognized nucleic-acid-type PAMP [49].

TLR also recognize endogenous damage-associated molecular patterns (DAMP) which are secreted from severe damaged host cells caused by any environmental stress, such as microbial infection or injury. Self-DNA/RNA, high-mobility group boxl (HMGB1), a DNA-binding nuclear protein, and self-HSP are included in the DAMP. These molecules were reported to be rapidly released following unprogrammed cell death and activate PRRexpressing cells similar to the PAMP [50]. Major TLR, PAMP, and DAMP were summarized in Table 1. In PAMP, bacterial lipopeptides, HSP, and LPS were recognized by TLR1/TLR2/TLR6, TLR2/TLR4, and TLR4 with CD14, respectively [46]. Similar mechanisms were found in DAMP with self-lipoproteins, self-HSP, and HMGB1. Two major TLR signaling pathways were demonstrated, namely, myeloid differentiation primary response protein (MyD)88-dependent pathway and Toll/interleukin receptor 1 (TIR) domain-containing adaptor-inducing IFN $\beta$ (TRIF)dependent pathway (Figure 5). With TLR stimulation, except TLR3, APC produced proinflammatory cytokines through MyD88 and activated mitogen-activated protein kinases (MAPK). APC produced type 1 IFN by utilizing of TRIF through TLR3 stimulation, an intracellular TLR [46].

\section{Th Cell Differentiation through TLR Stimulation}

Dendritic cells stimulated with TLR2 and TLR4 ligands produced IL-12 and IL-23 [51, 52]. APC secreted IL-27 through TLR3 and TLR4 signaling [53-55] and type 1 IFN enhanced the expression $[53,54]$. It was found that each IL-12 family subunit (Figure 2) had an expression pattern in APC through TLR4 stimulation [55]. For example, APC expressed p19 during early phase for a short time and produced p35 and p40 continuously in later phase. P28 acted as an intermediary between them. These data suggest that TLR stimulation may play a role in autocrine activation of APC by type 1 IFN induction (Figure 5) and the APC regulate T-cell differentiation though IL-12 family cytokines in a timedependent manner. 


\begin{tabular}{|c|c|c|c|c|c|c|c|c|}
\hline \multirow{2}{*}{$\begin{array}{l}\text { Cytokine } \\
\text { Subunit }\end{array}$} & \multicolumn{2}{|c|}{ IL-23 } & \multicolumn{2}{|c|}{ IL-12 } & \multicolumn{2}{|c|}{ IL-27 } & \multicolumn{2}{|c|}{ IL-35 } \\
\hline & p19 & $\mathrm{p} 40$ & p35 & $\mathrm{p} 40$ & $\mathrm{p} 28$ & Ebi3 & p35 & Ebi3 \\
\hline Receptor & IL-23R & IL-12R $\beta 1$ & IL- $12 \mathrm{R} \beta 2$ & IL-12R $\beta 1$ & IL-27R & gp130 & IL- $12 \mathrm{R} \beta 2$ & gp130 \\
\hline \multirow{3}{*}{$\begin{array}{l}\text { JAK-STAT } \\
\text { signaling } \\
\text { pathway }\end{array}$} & \multicolumn{2}{|c|}{ JAK2, TYK2 } & \multicolumn{2}{|c|}{ JAK2, TYK2 } & \multicolumn{2}{|c|}{ JAK1, JAK2 } & \multicolumn{2}{|c|}{ JAK1, JAK2 } \\
\hline & \multicolumn{2}{|c|}{$\begin{array}{c}\text { STAT1, STAT3, } \\
\text { STAT4, STAT5 } \\
\downarrow\end{array}$} & \multicolumn{2}{|c|}{$\begin{array}{c}\text { STAT4 } \\
\downarrow\end{array}$} & \multicolumn{2}{|c|}{$\begin{array}{c}\text { STAT1, STAT3 } \\
\downarrow\end{array}$} & \multirow{2}{*}{\multicolumn{2}{|c|}{$\begin{array}{c}\text { STAT1, STAT4 } \\
\downarrow \\
\text { IL-35?, IL-10?, } \\
\text { TGF } \beta ?\end{array}$}} \\
\hline & \multicolumn{2}{|c|}{ IL-17 } & \multicolumn{2}{|c|}{ IFN $\gamma$} & \multicolumn{2}{|c|}{ IL-10 } & & \\
\hline Function & \multicolumn{2}{|c|}{ Proinflammatory } & & & & & Anti-inflar & matory \\
\hline
\end{tabular}

FIGURE 2: A schematic representation of IL-12 family cytokines and the corresponding receptors and JAK-STAT signaling pathways [16]. IL12, IL-23, IL-27, and IL-35 are heterodimeric and share the subunits. The 4 cytokines require each corresponding receptor which also shares components for the function. It is thought that the 4 cytokines have overlapping but distinct effect on $\mathrm{T}$ cells with corresponding Janus kinase (JAK)-STAT signaling pathway. The experimental data demonstrated a functional spectrum from proinflammatory to inhibitory in Th cell differentiation. IL-12 and IL-23 are produced by activated dendritic cells and macrophages and induce inflammation through Th1 and Th17 differentiation, respectively. IL-27 is secreted from antigen-presenting cells and produces IL-10 secreting Th cells. IL-35 is mainly produced by Treg cells, amplifies IL-35 producing Th cells, and induces T-cell arrest.

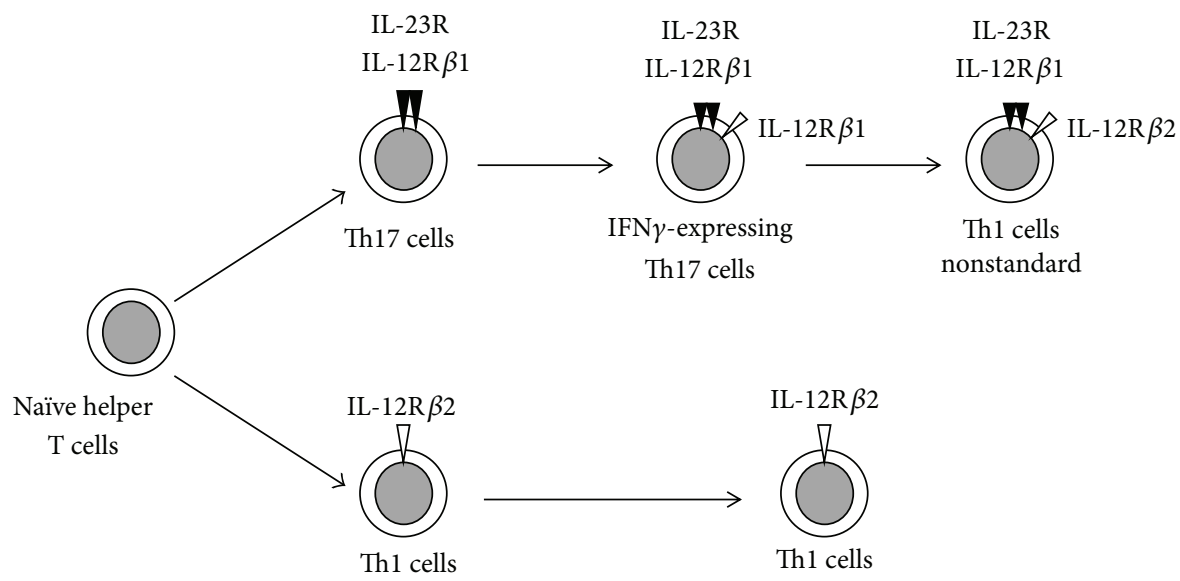

Figure 3: Th17 and Thl cell differentiations and the phenotype plasticity [24,25]. Th17 cell phenotype is not fixed in vitro and in vivo and Th17 cells can turn into IFN $\gamma$-expressing Thl7 cells and subsequently into nonstandard Thl cells. These two types of cells are thought to be more pathogenic and have higher affinity for inflammatory lesions than original Th17 cells.

Th cells are suggested to express TLR [14]. T-cell receptor (TCR) stimulation activates $\mathrm{T}$ cells by phosphorylation of extracellular signal-regulated kinases (ERK)1/2, both of which are subsets of MAPK family. TLR2 costimulation to the human TCR signaling promoted the phosphorylation and directly modulated the T-cell differentiation [56]. Several researchers demonstrated that TLR2 signaling without APC led to the induction of not only Th1 [57-59] and Th17 [60] cells but also Treg cells [57] in mouse experiments. Human naive and Treg cells converted into Th17 cells with stimulation of TLR ligands [61]. In human infectious disease, TLR2 receptor on Th cells of patients with tuberculosis was overexpressed and its stimulation caused a marked activation of the cells [62]. In contrast, underexpression of TLR2 on Th cells and lower secretion of IFN $\gamma$ by TLR stimulation were observed in patients with filarial infection [63]. A possibility was considered that the repeated antigen exposure may explain the discrepancy [14].

Experimental approaches demonstrated various aspects of the relationship between TCR and TLR4 stimulation. TLR4 co-stimulation inhibited ERK1/2 phosphorylation of Th cells in mice [64] and TCR signaling with a pretreatment of LPS decreased activated MAPK [58]. TLR4 co-stimulation did not directly regulate Th cell differentiation, but selective deletion of TLR4 in Th cells decreased IFN $\gamma$ and IL-17 production at experimentally inflammatory sites [65].

These results suggest a need to assess the molecular relationship between MAPK/ERK and JAK/STAT signaling pathways in Th cell differentiation under both physiological and pathological conditions.

\section{Possible Effects of HSP on Th Cell Activation as Both PAMP and DAMP}

HSP are highly conserved and ubiquitously expressed proteins and function as an intracellular chaperonin for other proteins. An HSP was found as a remarkably increased factor in Drosophila salivary glands with "heat shock" in the first study. After numerous studies, subgroups of HSP were named 
TABLE 1: TLR and corresponding PAMP and DAMP $[46,50]$.

\begin{tabular}{lll}
\hline TLR & PAMP & DAMP \\
\hline TLR1 & Bacterial lipopeptide & \\
TLR2 & HSP (mycobacteria, Chlamydia), LPS, bacterial lipopeptide, peptidoglycan & HSP, HMGB1, and lipoprotein \\
TLR3 & Viral RNA & Self-RNA \\
TLR4 & HSP (mycobacteria, Chlamydia), LPS & HSP60, HSP70, HMGB1, and lipoprotein \\
TLR6 & Bacterial lipopeptide & \\
TLR7 & Viral and bacterial RNA & Chromatin and ribonucleoprotein, self-DNA \\
TLR9 & Viral, bacterial and parasitic DNA & HSP, chromatin and ribonucleoprotein, and self-DNA \\
\hline
\end{tabular}

TLR: Toll-like receptors; DAMP: damage-associated molecular patterns; PAMP: pathogen-associated molecular patterns; HSP: heat shock proteins; HMGB1: high-mobility group boxl; LPS: lipopolysaccharide.
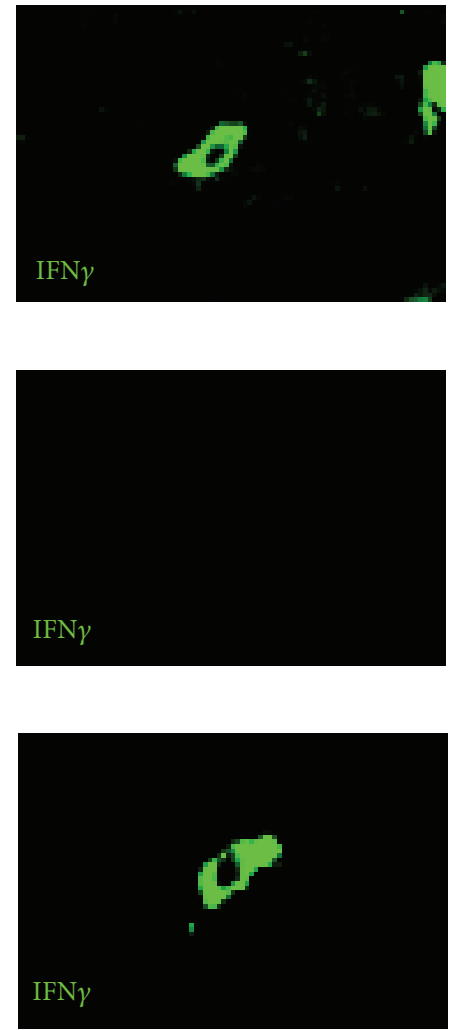

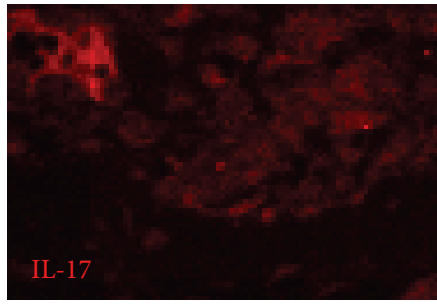

(a)



(b)

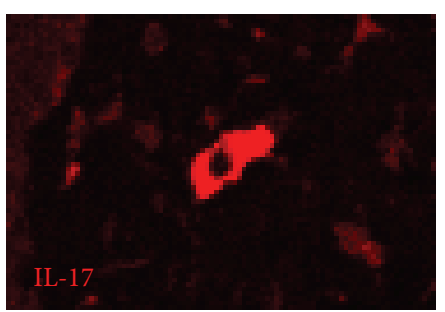

(c)
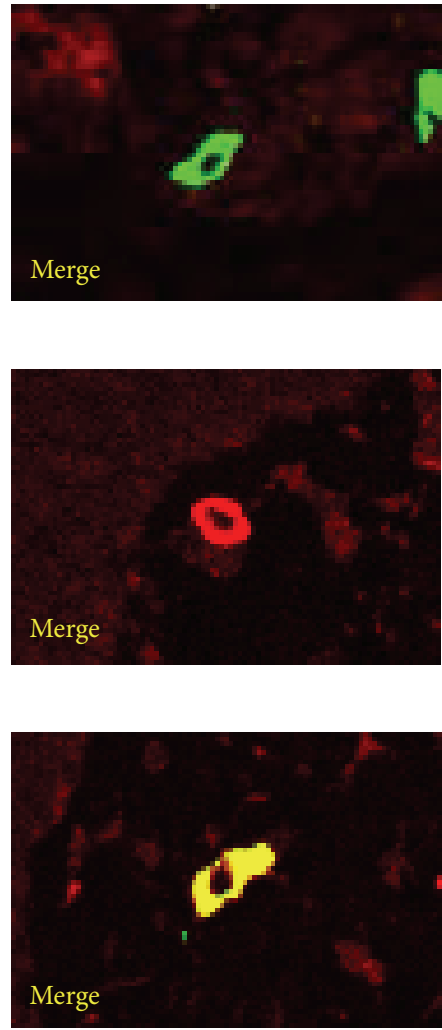

FIgURE 4: Immunofluorescence of Th1, Th17, and IFN $\gamma$-expressing Th17 cells in a BD skin lesion. (a) Th1 cell, (b) Th17 cell, and (c) IFN $\gamma$ expressing Th17 cell were simultaneously observed in one skin specimen obtained from erythema-nodosum-like lesion of BD.

for their molecular weights and subdivided into two major functional systems. HSP60-HSP10 system assisted the adequate protein folding and HSP70-HSP40 system was involved in the stability of cytosol peptides [66]. Significant sequence homology is found between mammalian and microbial HSP. For example, mycobacterial and streptococcal HSP65 have more than 90\% homology, and mycobacterial HSP65 and human HSP60 have 42\% homology [67].

It was suggested that HSP were secreted from both microbes and necrotic cells and were recognized by TLR2 and TLR4 [46]. In several studies, HSP were categorized into both PAMP and DAMP (Table 1) [50, 68]. Certainly, clinical studies demonstrated that HSP accumulation was promoted in the lesions of several human autoimmune diseases [6972]. HSP peptide-specific $T$ cells were found in patients with type 1 diabetes [73, 74], rheumatoid arthritis [75], and juvenile idiopathic arthritis [76]. Several experimental model studies of autoimmunity reported protective effects of HSP peptide by deletion of peptide specific T cells [77]. In fact, oral administration of an HSP peptide successfully increased Treg cells [75] and reduced disease activity in patients with rheumatoid arthritis [78]. 


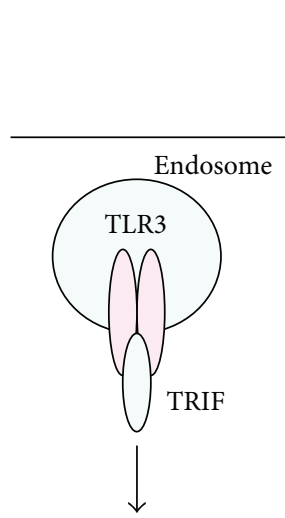

Type 1 IFN
Plasma membrane

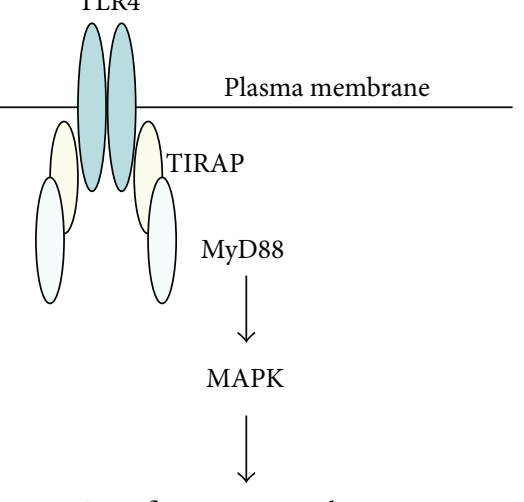

Proinflammatory cytokines
FIgUre 5: Two major TLR signaling pathways [48]. With TLR stimulation, except TLR3, APC produced proinflammatory cytokines through MyD88 and activated mitogen-activated protein kinases (MAPK). APC produced type 1 IFN by utilizing of TRIF through TLR3 stimulation, an intracellular TLR. TIRAP: Toll/interleukin 1 receptor (TIR) domain containing adaptor protein, MyD88: myeloid differentiation primary response protein 88 , TRIF: TIR domaincontaining adaptor-inducing IFN $\beta$, MAPK: mitogen-activated protein kinases, and IFN: interferon.

\section{TLR and HSP Involvement in BD}

Clinical studies demonstrated that both TLR and HSP expressions increased in patients with $\mathrm{BD}$. Elevated gene expressions of TLR2 and TLR4 were found in peripheral blood monocytes [79], PBMC [80], polymorphonuclear leukocytes [80], bronchoalveolar lavage leukocytes [81], and oral mucosa [82] in patients with BD compared to normal controls. TLR2and TLR4-positive cells in buccal lesions [83] and TLR6positive polymorphonuclear leukocytes cultured with HSP60 [84] were significantly increased in patients with BD.

Several researchers observed massive expressions of HSP60 in BD skin [85] and oral ulcer lesions [86, 87]. HSP60 was expressed more diffusely [87] and intensely $[85,87]$ in $\mathrm{BD}$ lesions than those in other types of inflammation, such as oral lichen planus and recurrent aphthous stomatitis. Excessive Tand B-cell responses to major four peptides of Mycobacterium tuberculosis HSP65 and human counterparts of HSP60 were observed in patients with BD who lived in Europe, FarEastern Asia, and Middle East [10, 88-90].

We have found that TLR2 and TLR4 mRNA were expressed on ileocaecal ulcer lesions of $\mathrm{BD}$, but less on unaffected sites of BD and on Crohn's disease lesions. IL-12 producing TLR2 positive macrophages located neighboring to T cells and HSP60 was expressed on the same region of the intestinal lesions $[8,9]$. C-C-type chemokine receptor (CCR) 5 and macrophage inflammatory protein (MIP) $1 \beta$, a Th1 related chemokine receptor and its ligand, were detected in the intestinal lesions of BD and CCR5/MIP1 $\beta$ interaction was thought to play a role in the migration of activated Th1 cells [9]. Moreover, we have reported that Th cells yielded proliferative responses to human HSP60 peptide in Japanese BD patients by a TCR V $\beta$ gene restricted antigen-driven process [90]. We suggest that TLR/HSP60 interactions induce destructive Thl-type responses at the intestinal lesion in patients with $\mathrm{BD}[91]$.

\section{Genetic Variations of IL-12 Family Genes in BD and Human Autoimmune Diseases}

Detailed analysis of comorbidity in dozens of human autoimmune diseases revealed the importance of treating the diseases as one group and suggested that there were several common etiopathologies among the diseases [92]. In the past decade, genetic clustering in the human autoimmune diseases has progressed with Genome-Wide Association studies (GWAS) to invest underlying genetic factors. Particulary, there have been noteworthy advances in the research of genetic variants in IL-12-family-related genes, which have shown major two subclusters, namely, Th17/Th1 cluster and Th1/IL-35 cluster (Figure 6) [93]. Th17/Th1 cluster was related to the polymorphisms of IL-23R and IL-12B and affiliated with inflammatory bowel diseases [94], psoriasis [95], ankylosing spondylitis [96], and rheumatoid arthritis [97]. Th1/IL35 cluster was related to the polymorphisms of IL-12A and IL$12 \mathrm{R} \beta 2$ and affiliated with primary biliary cirrhosis [98] and Graves' disease (Figure 6) [99]. Several studies suggest that celiac disease [100] and multiple sclerosis [101] show both clusters' polymorphisms (Figure 6).

A decade of GWAS was conducted for BD in Turkey [102104], Japan [105, 106], China [107], Iran [108], and Korea [109]. Human leukocyte antigen (HLA)-B51 is the most strongly associated risk factor for $\mathrm{BD}$ by a meta-analysis of case control genetic association studies [110] and the GWAS data support the result $[102,103,106]$. Recent two major studies $[103,105]$ identified MHC class I locus, IL-10, and IL-23R-IL12RB2 as $\mathrm{BD}$ susceptibility genes. IL-10 is an inhibitory cytokine to both T cells and APC [111], and secreted from T cells under IL-27 stimulation, as it was previously mentioned in Section 2. IL-10 production of healthy donors' PBMC with a BD-associated allele was significantly decreased compared to that without the allele in the presence of LPS [103]. Other several studies reported that, adding to IL-10 [108] and IL23R-IL12RB2 [108, 109], STAT4 [107, 109] and IL-17A [109] genes were associated with $\mathrm{BD}$. These data indicated a possibility that BD was included in Th17/Th1 cluster according to the above-mentioned clustering analysis. The IL-12 family cytokine gene polymorphisms suggest that the function of each IL-12 family cytokine subunit molecule needs to be reinvestigated based on the clustering analysis in patients with BD.

\section{Genetic Variations of TLR and HSP in BD and Human Immune Diseases}

Researchers mentioned that TLR gene polymorphisms were associated with several allergic and inflammatory diseases [112-116]. Skewed monocyte and mononuclear cell responses in cytokine production against microbe extracts were found in atopic dermatitis and asthma patients with a TLR2 [112] and a TLR4 [113] polymorphisms, respectively. 


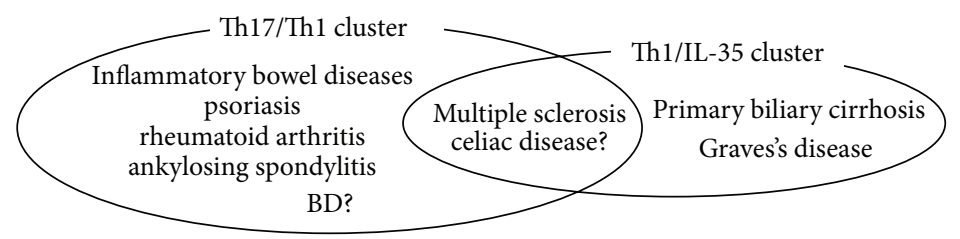

FIGURE 6: IL-12-family-cytokine-related genetic polymorphisms were found to be associated with several human immune diseases [44]. Th17/Th1 cluster was related to the polymorphisms of IL-23R and IL-12B and affiliated with inflammatory bowel diseases, psoriasis, ankylosing spondylitis, and rheumatoid arthritis. Th1/IL-35 cluster was related to the polymorphisms of IL-12A and IL-12R $\beta 2$, and affiliated with primary biliary cirrhosis and Graves's disease. Several studies suggest that celiac disease and multiple sclerosis show both clusters' polymorphisms. Several Genome-Wide Association Studies identified IL-23R-IL12RB2, STAT4, and IL-17A as BD susceptibility genes and indicated a possibility that $\mathrm{BD}$ was including in Th17/Th1 cluster.

Several TLR gene polymorphism studies in patients with $\mathrm{BD}$ demonstrated no association with susceptibility to BD [117-124]. Recently, a targeted resequencing study was undertaken to detect rare genetic variants and, adding to IL23R, TLR4 and nucleotide-binding oligomerization domain 2 (NOD2) genes, the latter of which was an intracellular PRR, were found to be associated with BD [125]. MyD88 adaptor-like protein (Mal), also known as TIR domaincontaining adaptor protein (TIRAP, Figure 5), polymorphism was suggested to be associated with $\mathrm{BD}$ in UK [83]. TLR2 and TLR4 use TIRAP as an additional adaptor to recruit MyD88 [46]. The two studies offered new approaches for identifying $\mathrm{BD}$ susceptibility gene. Moreover, Killer cell lectin-like receptor subfamily C, member 4 (KLRC4) gene, a natural killer cell receptor, and endoplasmic reticular aminopeptidase 1 (ERAP1) gene, a major immunoregulatory molecule by peptide trimming inside the reticulum, were identified as BD susceptibility genes [102]. These analyses of gene polymorphisms in $\mathrm{BD}$, with the high susceptibility of HLA-B51, indicated the importance of innate immune function as an effective therapeutic target in patients with $\mathrm{BD}$. In fact, inhibitors of tumor necrosis factor $\alpha$, a downstream effector cytokine of MAPK signaling pathway in APC with TLR4 stimulation, remarkably ameliorated clinical symptoms in patients with $\mathrm{BD}[126,127]$.

It was reported that HSP and the promoter gene polymorphisms were associated with Crohn's disease [128], bacterial sepsis [129], and multiple organ dysfunction after severe trauma [130]. HSP genes may serve as important factors for the detection of BD susceptibility gene.

\section{Conclusions}

We reviewed here current concept in Th cell differentiation and the functional/genetic contribution of the cells to the pathogenesis of BD. Skewed IL-12 family cytokine responses and related genetic variants were suggested to play a crucial role in the pathophysiological conditions in BD. Interestingly, dysregulation of Th17/Th1 cells and genetic variation in IL12 gene family were found in several human autoimmune diseases. The existence of genetic variants both in innate and adaptive immune responses suggests that it is important to understand the molecular mechanical differences in the
Th cell responses of $\mathrm{BD}$ between with and without $\mathrm{APC}$ of the patients with $\mathrm{BD}$.

\section{Acknowledgments}

Our works were supported in part by Grants from Behcet's Disease Research Committee, Research on Specific Disease of the Health Science Research Grants from the Ministry of Health, Labor and Welfare, Japan.

\section{References}

[1] T. Sakane, M. Takeno, N. Suzuki, and G. Inaba, "Behcet's disease," The New England Journal of Medicine, vol. 341, no. 17, pp. 1284-1291, 1999.

[2] M. Melikoglu, S. Uysal, J. G. Krueger et al., "Characterization of the divergent wound-healing responses occurring in the pathergy reaction and normal healthy volunteers," The Journal of Immunology, vol. 177, no. 9, pp. 6415-6421, 2006.

[3] M. Ben Ahmed, H. Houman, M. Miled, K. Dellagi, and H. Louzir, "Involvement of chemokines and Thl cytokines in the pathogenesis of mucocutaneous lesions of Behçet's disease," Arthritis and Rheumatism, vol. 50, no. 7, pp. 2291-2295, 2004.

[4] S. Koarada, Y. Haruta, Y. Tada et al., "Increased entry of CD $4^{+} \mathrm{T}$ cells into the Thl cytokine effector pathway during T-cell division following stimulation in Behçet's disease," Rheumatology, vol. 43, no. 7, pp. 843-851, 2004.

[5] H. Houman, A. Hamzaoui, I. Ben Ghorbal, M. Khanfir, M. Feki, and K. Hamzaoui, "Abnormal expression of chemokine receptors in Behçet's disease: relationship to intracellular Th1/Th2 cytokines and to clinical manifestations," Journal of Autoimmunity, vol. 23, no. 3, pp. 267-273, 2004.

[6] F. Ilhan, T. Demir, P. Türkçüoğlu, B. Turgut, N. Demir, and A. Gödekmerdan, "Th1 polarization of the immune response in uveitis in Behçet's disease," Canadian Journal of Ophthalmology, vol. 43, no. 1, pp. 105-108, 2008.

[7] A. M. Dalghous, J. Freysdottir, and F. Fortune, "Expression of cytokines, chemokines, and chemokine receptors in oral ulcers of patients with Behcet's disease (BD) and recurrent aphthous stomatitis is Th1-associated, although Th2-association is also observed in patients with BD," Scandinavian Journal of Rheumatology, vol. 35, no. 6, pp. 472-475, 2006.

[8] K. Nara, M. S. Kurokawa, S. Chiba et al., "Involvement of innate immunity in the pathogenesis of intestinal Behçet's disease," Clinical and Experimental Immunology, vol. 152, no. 2, pp. 245251, 2008. 
[9] Y. Imamura, M. S. Kurokawa, H. Yoshikawa et al., "Involvement of Th1 cells and heat shock protein 60 in the pathogenesis of intestinal Behçet's disease," Clinical and Experimental Immunology, vol. 139, no. 2, pp. 371-378, 2005.

[10] H. Nagafuchi, M. Takeno, H. Yoshikawa et al., "Excessive expression of Txk, a member of the Tec family of tyrosine kinases, contributes to excessive Thl cytokine production by T lymphocytes in patients with Behcet's disease," Clinical and Experimental Immunology, vol. 139, no. 2, pp. 363-370, 2005.

[11] H. Yanagihori, N. Oyama, K. Nakamura, N. Mizuki, K. Oguma, and F. Kaneko, "Role of IL-12B promoter polymorphism in Adamantiades-Behcet's disease susceptibility: an involvement of Thl immunoreactivity against Streptococcus sanguinis antigen," Journal of Investigative Dermatology, vol. 126, no. 7, pp. 1534-1540, 2006.

[12] M. T. Palmer and C. T. Weaver, "Autoimmunity: increasing suspects in the $\mathrm{CD} 4^{+} \mathrm{T}$ cell lineup," Nature Immunology, vol. 11, no. 1, pp. 36-40, 2010.

[13] R. Basu, R. D. Hatton, and C. T. Weaver, "The Thl7 family: flexibility follows function," Immunological Reviews, vol. 252, no. 1, pp. 89-103, 2013.

[14] J. M. Reynolds and C. Dong, "Toll-like receptor regulation of effector T lymphocyte function," Trends in Immunology, vol. 34, no. 10, pp. 511-519, 2013.

[15] L. Lu, J. Wang, F. Zhang et al., "Role of SMAD and non-SMAD signals in the development of Th17 and regulatory T cells," The Journal of Immunology, vol. 184, no. 8, pp. 4295-4306, 2010.

[16] E. Bettelli, Y. Carrier, W. Gao et al., "Reciprocal developmental pathways for the generation of pathogenic effector TH17 and regulatory T cells," Nature, vol. 441, no. 7090, pp. 235-238, 2006.

[17] D. A. Vignali and V. K. Kuchroo, "IL-12 family cytokines: immunological playmakers," Nature Immunology, vol. 13, no. 8, pp. 722-728, 2012.

[18] R. M. Pope and S. Shahrara, "Possible roles of IL-12-family cytokines in rheumatoid arthritis," Nature Reviews, Rheumatology, vol. 9, no. 4, pp. 252-256, 2013.

[19] C. Parham, M. Chirica, J. Timans et al., "A receptor for the heterodimeric cytokine IL-23 is composed of IL-12R $\beta 1$ and a novel cytokine receptor subunit, IL-23R," The Journal of Immunology, vol. 168, no. 11, pp. 5699-5708, 2002.

[20] J. S. Stumhofer, J. S. Silver, A. Laurence et al., "Interleukins 27 and 6 induce STAT3-mediated T cell production of interleukin 10," Nature Immunology, vol. 8, no. 12, pp. 1363-1371, 2007.

[21] L. W. Collison, C. J. Workman, T. T. Kuo et al., "The inhibitory cytokine IL-35 contributes to regulatory T-cell function," Nature, vol. 450, no. 7169, pp. 566-569, 2007.

[22] E. Bardel, F. Larousserie, P. Charlot-Rabiega, A. CoulombL'Herminé, and O. Devergne, "Human $\mathrm{CD} 4{ }^{+} \mathrm{CD} 25^{+} \mathrm{Foxp}^{+}$ regulatory $\mathrm{T}$ cells do not constitutively express IL-35," The Journal of Immunology, vol. 181, no. 10, pp. 6898-6905, 2008.

[23] C. Garbers, H. M. Hermanns, F. Schaper et al., "Plasticity and cross-talk of interleukin 6-type cytokines," Cytokine \& Growth Factor Reviews, vol. 23, no. 3, pp. 85-97, 2012.

[24] F. Annunziato, L. Cosmi, F. Liotta, E. Maggi, and S. Romagnani, "Defining the human T helper 17 cell phenotype," Trends in Immunology, vol. 33, no. 10, pp. 505-512, 2012.

[25] P. Muranski and N. P. Restifo, "Essentials of Th17 cell commitment and plasticity," Blood, vol. 121, no. 13, pp. 2402-2414, 2013.

[26] N. J. Wilson, K. Boniface, J. R. Chan et al., "Development, cytokine profile and function of human interleukin 17producing helper T cells," Nature Immunology, vol. 8, no. 9, pp. 950-957, 2007.
[27] B. W. Kirkham, M. N. Lassere, J. P. Edmonds et al., "Synovial membrane cytokine expression is predictive of joint damage progression in rheumatoid arthritis: a two-year prospective study (the DAMAGE study cohort)," Arthritis and Rheumatism, vol. 54, no. 4, pp. 1122-1131, 2006.

[28] L. J. Edwards, R. A. Robins, and C. S. Constantinescu, "Th17/Th1 phenotype in demyelinating disease," Cytokine, vol. 50, no. 1, pp. 19-23, 2010.

[29] Z. Hovhannisyan, J. Treatman, D. R. Littman, and L. Mayer, "Characterization of interleukin-17-producing regulatory $\mathrm{T}$ cells in inflamed intestinal mucosa from patients with inflammatory bowel diseases," Gastroenterology, vol. 140, no. 3, pp. 957-965, 2011.

[30] F. Annunziato, L. Cosmi, V. Santarlasci et al., "Phenotypic and functional features of human Th17 cells," The Journal of Experimental Medicine, vol. 204, no. 8, pp. 1849-1861, 2007.

[31] A. Hänsel, C. Günther, J. Ingwersen et al., "Human slan (6-sulfo LacNAc) dendritic cells are inflammatory dermal dendritic cells in psoriasis and drive strong Th17/Th1 T-cell responses," Journal of Allergy and Clinical Immunology, vol. 127, no. 3, pp. 787-794, 2011.

[32] H. Kebir, I. Ifergan, J. I. Alvarez et al., "Preferential recruitment of interferon- $\gamma$-expressing TH17 cells in multiple sclerosis," Annals of Neurology, vol. 66, no. 3, pp. 390-402, 2009.

[33] K. Nistala, S. Adams, H. Cambrook et al., "Th17 plasticity in human autoimmune arthritis is driven by the inflammatory environment," Proceedings of the National Academy of Sciences of the United States of America, vol. 107, no. 33, pp. 14751-14756, 2010.

[34] L. Cosmi, R. Cimaz, L. Maggi et al., "Evidence of the transient nature of the Th17 phenotype of $\mathrm{CD}^{+} \mathrm{CD} 161^{+} \mathrm{T}$ cells in the synovial fluid of patients with juvenile idiopathic arthritis," Arthritis and Rheumatism, vol. 63, no. 8, pp. 2504-2515, 2011.

[35] M. Miyara, G. Gorochov, M. Ehrenstein, L. Musset, S. Sakaguchi, and Z. Amoura, "Human FoxP3 ${ }^{+}$regulatory T cells in systemic autoimmune diseases," Autoimmunity Reviews, vol. 10, no. 12, pp. 744-755, 2011.

[36] S. Sakaguchi, D. A. Vignali, A. Y. Rudensky, R. E. Niec, and H. Waldmann, "The plasticity and stability of regulatory T cells," Nature Reviews Immunology, vol. 13, no. 6, pp. 461-467, 2013.

[37] X. O. Yang, R. Nurieva, G. J. Martinez et al., "Molecular antagonism and plasticity of regulatory and inflammatory $\mathrm{T}$ cell programs," Immunity, vol. 29, no. 1, pp. 44-56, 2008.

[38] N. Ohkura, Y. Kitagawa, and S. Sakaguchi, "Development and maintenance of regulatory T cells," Immunity, vol. 38, no. 3, pp. 414-423, 2013.

[39] K. Hamzaoui, E. Bouali, I. Ghorbel, M. Khanfir, H. Houman, and A. Hamzaoui, "Expression of Th-17 and ROR $\gamma \mathrm{t}$ mRNA in Behçet's disease," Medical Science Monitor, vol. 17, no. 4, pp. CR227-CR234, 2011.

[40] J. Shimizu, K. Takai, N. Fujiwara et al., "Excessive CD4 ${ }^{+}$T cells co-expressing interleukin-17 and interferon- $\gamma$ in patients with Behçet's disease," Clinical and Experimental Immunology, vol. 168, no. 1, pp. 68-74, 2012.

[41] G. Geri, B. Terrier, M. Rosenzwajg et al., "Critical role of IL-21 in modulating TH17 and regulatory T cells in Behet disease," Journal of Allergy and Clinical Immunology, vol. 128, no. 3, pp. 655-664, 2011.

[42] Y. Nanke, S. Kotake, M. Goto, H. Ujihara, M. Matsubara, and N. Kamatani, "Decreased percentages of regulatory T cells in peripheral blood of patients with Behcet's disease before ocular 
attack: a possible predictive marker of ocular attack," Modern Rheumatology, vol. 18, no. 4, pp. 354-358, 2008.

[43] W. Chi, X. Zhu, P. Yang et al., "Upregulated IL-23 and IL-17 in Behçet patients with active uveitis," Investigative Ophthalmology and Visual Science, vol. 49, no. 7, pp. 3058-3064, 2008.

[44] J. Shimizu, T. Izumi, N. Arimitsu et al., "Skewed TGF $\beta /$ Smad signaling pathway of T cells in patients with Behcet's disease," Clinical and Experimental Rheumatology, vol. 30, supplement 72, pp. S35-S39, 2012.

[45] A. Osterloh and M. Breloer, "Heat shock proteins: linking danger and pathogen recognition," Medical Microbiology and Immunology, vol. 197, no. 1, pp. 1-8, 2008.

[46] S. Akira, S. Uematsu, and O. Takeuchi, "Pathogen recognition and innate immunity," Cell, vol. 124, no. 4, pp. 783-801, 2006.

[47] C. A. Janeway Jr., U. Dianzani, P. Portoles et al., "Cross-linking and conformational change in T-cell receptors: role in activation and in repertoire selection," Cold Spring Harbor Symposia on Quantitative Biology, vol. 54, no. 2, pp. 657-666, 1989.

[48] T. Kawai and S. Akira, "Toll-like receptors and their crosstalk with other innate receptors in infection and immunity," Immunity, vol. 34, no. 5, pp. 637-650, 2011.

[49] A. L. Blasius and B. Beutler, "Intracellular toll-like receptors," Immunity, vol. 32, no. 3, pp. 305-315, 2010.

[50] A. M. Piccinini and K. S. Midwood, "DAMPening inflammation by modulating TLR signalling," Mediators of Inflammation, vol. 2010, Article ID 672395, 21 pages, 2010.

[51] M. Schnare, G. M. Barton, A. C. Holt, K. Takeda, S. Akira, and R. Medzhitov, "Toll-like receptors control activation of adaptive immune responses," Nature Immunology, vol. 2, no. 10, pp. 947950, 2001.

[52] A. F. Heiseke, A. C. Faul, H. Lehr et al., "CCL17 promotes intestinal inflammation in mice and counteracts regulatory $\mathrm{T}$ cellmediated protection from colitis," Gastroenterology, vol. 142, no. 2, pp. 335-345, 2012.

[53] M. E. Remoli, V. Gafa, E. Giacomini, M. Severa, R. Lande, and E. M. Coccia, "IFN- $\beta$ modulates the response to TLR stimulation in human DC: involvement of IFN regulatory factor-1 (IRF-1) in IL-27 gene expression," European Journal of Immunology, vol. 37, no. 12, pp. 3499-3508, 2007.

[54] J. Pirhonen, J. Sirén, I. Julkunen, and S. Matikainen, "IFN- $\alpha$ regulates toll-like receptor-mediated IL-27 gene expression in human macrophages," Journal of Leukocyte Biology, vol. 82, no. 5, pp. 1185-1192, 2007.

[55] N. Schuetze, S. Schoeneberger, U. Mueller, M. A. Freudenberg, G. Alber, and R. K. Straubinger, "IL-12 family members: differential kinetics of their TLR4-mediated induction by Salmonella enteritidis and the impact of IL-10 in bone marrow-derived macrophages," International Immunology, vol. 17, no. 5, pp. 649659, 2005.

[56] N. M. Chapman, M. Y. Bilal, N. Cruz-Orcutt et al., "Distinct signaling pathways regulate TLR2 co-stimulatory function in human T cells," Cellular Signalling, vol. 25, no. 3, pp. 639-650, 2013.

[57] H. Liu, M. Komai-Koma, D. Xu, and F. Y. Liew, “Toll-like receptor 2 signaling modulates the functions of $\mathrm{CD} 4^{+} \mathrm{CD} 25^{+}$ regulatory T cells," Proceedings of the National Academy of Sciences of the United States of America, vol. 103, no. 18, pp. 7048-7053, 2006.

[58] T. Imanishi, H. Hara, S. Suzuki, N. Suzuki, S. Akira, and T. Saito, "Cutting edge: TLR2 directly triggers Th1 effector functions," The Journal of Immunology, vol. 178, no. 11, pp. 6715-6719, 2007.
[59] A. Biswas, P. Banerjee, and T. Biswas, "Porin of Shigella dysenteriae directly promotes toll-like receptor 2 -mediated $\mathrm{CD} 4^{+} \mathrm{T}$ cell survival and effector function," Molecular Immunology, vol. 46, no. 15, pp. 3076-3085, 2009.

[60] J. M. Reynolds, B. P. Pappu, J. Peng et al., “Toll-like receptor 2 signaling in $\mathrm{CD}^{+}{ }^{+} \mathrm{T}$ lymphocytes promotes $\mathrm{T}$ helper 17 responses and regulates the pathogenesis of autoimmune disease," Immunity, vol. 32, no. 5, pp. 692-702, 2010.

[61] M. H. Nyirenda, L. Sanvito, P. J. Darlington et al., “TLR2 stimulation drives human naive and effector regulatory $\mathrm{T}$ cells into a Th17-like phenotype with reduced suppressive function," The Journal of Immunology, vol. 187, no. 5, pp. 2278-2290, 2011.

[62] X. Chen, M. Zhang, X. Zhu et al., "Engagement of toll-like receptor 2 on $\mathrm{CD}^{+} \mathrm{T}$ cells facilitates local immune responses in patients with tuberculous pleurisy," Journal of Infectious Diseases, vol. 200, no. 3, pp. 399-408, 2009.

[63] S. Babu, C. P. Blauvelt, V. Kumaraswami, and T. B. Nutman, "Cutting edge: diminished T cell TLR expression and function modulates the immune response in human filarial infection," The Journal of Immunology, vol. 176, no. 7, pp. 3885-3889, 2006.

[64] J. M. González-Navajas, S. Fine, J. Law et al., “TLR4 signaling in effector $\mathrm{CD} 4^{+} \mathrm{T}$ cells regulates TCR activation and experimental colitis in mice," The Journal of Clinical Investigation, vol. 120, no. 2, pp. 570-581, 2010.

[65] J. M. Reynolds, G. J. Martinez, Y. Chung, and C. Dong, “Tolllike receptor 4 signaling in $\mathrm{T}$ cells promotes autoimmune inflammation," Proceedings of the National Academy of Sciences of the United States of America, vol. 109, no. 32, pp. 13064-13069, 2012.

[66] J. C. Young, V. R. Agashe, K. Siegers, and F. U. Hartl, "Pathways of chaperone-mediated protein folding in the cytosol," Nature Reviews Molecular Cell Biology, vol. 5, no. 10, pp. 781-791, 2004.

[67] A. K. Dudani and R. S. Gupta, "Immunological characterization of a human homolog of the 65-kilodalton mycobacterial antigen," Infection and Immunity, vol. 57, no. 9, pp. 2786-2793, 1989.

[68] G. Y. Chen and G. Nuñez, "Sterile inflammation: sensing and reacting to damage," Nature Reviews Immunology, vol. 10, no. 12, pp. 826-837, 2010.

[69] Q.-Q. Huang, R. Sobkoviak, A. R. Jockheck-Clark et al., "Heat shock protein 96 is elevated in rheumatoid arthritis and activates macrophages primarily via TLR2 signaling," The Journal of Immunology, vol. 182, no. 8, pp. 4965-4973, 2009.

[70] C. J. P. Boog, E. R. de Graeff-Meeder, M. A. Lucassen et al., “Two monoclonal antibodies generated against human hsp60 show reactivity with synovial membranes of patients with juvenile chronic arthritis," The Journal of Experimental Medicine, vol. 175, no. 6, pp. 1805-1810, 1992.

[71] E. F. Elst, M. Klein, W. De Jager et al., "Hsp60 in inflamed muscle tissue is the target of regulatory autoreactive T cells in patients with juvenile dermatomyositis," Arthritis and Rheumatism, vol. 58, no. 2, pp. 547-555, 2008.

[72] G. L. Puga Yung, M. Fidler, E. Albani et al., "Heat shock proteinderived T-cell epitopes contribute to autoimmune inflammation in pediatric Crohn's disease," PLoS ONE, vol. 4, no. 11, Article ID e7714, 2009.

[73] D. O. Sobel and K. Creswell, "Characterization of anti-islet cytotoxic human T-cell clones from patients with type 1 diabetes mellitus," Autoimmunity, vol. 39, no. 4, pp. 323-332, 2006.

[74] H. Jiang, S. M. Canfield, M. P. Gallagher et al., "HLA-Erestricted regulatory $\mathrm{CD}^{+} \mathrm{T}$ cells are involved in development 
and control of human autoimmune type 1 diabetes," The Journal of Clinical Investigation, vol. 120, no. 10, pp. 3641-3650, 2010.

[75] B. J. Prakken, R. Samodal, T. D. Le et al., "Epitope-specific immunotherapy induces immune deviation of proinflammatory T cells in rheumatoid arthritis," Proceedings of the National Academy of Sciences of the United States of America, vol. 101, no. 12, pp. 4228-4233, 2004.

[76] C.-T. C. Wu, L.-S. Ou, K.-W. Yeh, W.-I. Lee, and J.-L. Huang, "Serum heat shock protein 60 can predict remission of flare-up in juvenile idiopathic arthritis," Clinical Rheumatology, vol. 30, no. 7, pp. 959-965, 2011.

[77] E. Zonneveld-Huijssoon, S. Albani, B. J. Prakken, and F. van Wijk, "Heat shock protein bystander antigens for peptide immunotherapy in autoimmune disease," Clinical and Experimental Immunology, vol. 171, no. 1, pp. 20-29, 2013.

[78] E. C. Koffeman, M. Genovese, D. Amox et al., "Epitope-specific immunotherapy of rheumatoid arthritis: clinical responsiveness occurs with immune deviation and relies on the expression of a cluster of molecules associated with $\mathrm{T}$ cell tolerance in a double-blind, placebo-controlled, pilot phase II trial," Arthritis and Rheumatism, vol. 60, no. 11, pp. 3207-3216, 2009.

[79] J. E. Do, S. Y. Kwon, S. Park, and E.-S. Lee, "Effects of vitamin D on expression of toll-like receptors of monocytes from patients with Behçet's disease," Rheumatology, vol. 47, no. 6, pp. 840-848, 2008.

[80] Y. Kirino, M. Takeno, R. Watanabe et al., "Association of reduced heme oxygenase-1 with excessive toll-like receptor 4 expression in peripheral blood mononuclear cells in Behçet's disease," Arthritis Research and Therapy, vol. 10, no. 1, article R16, 2008.

[81] K. Hamzaoui, H. Abid, A. Berraies, J. Ammar, and A. Hamzaoui, "NOD2 is highly expressed in Behçet disease with pulmonary manifestations," Journal of Inflammation, vol. 9, no. 1, article 3, 2012.

[82] N. Seoudi, L. A. Bergmeier, E. Hagi-Pavli, D. Bibby, M. A. Curtis, and F. Fortune, "The role of TLR2 and 4 in Behcet's disease pathogenesis," Innate Immunity, 2013.

[83] O. Durrani, K. Banahan, F. J. Sheedy et al., "TIRAP Ser180Leu polymorphism is associated with Behçet's disease," Rheumatology, vol. 50, no. 10, pp. 1760-1765, 2011.

[84] S. Yavuz, Y. Elbir, A. Tulunay, E. Eksioglu-Demiralp, and H. Direskeneli, "Differential expression of toll-like receptor 6 on granulocytes and monocytes implicates the role of microorganisms in Behcet's disease etiopathogenesis," Rheumatology International, vol. 28, no. 5, pp. 401-406, 2008.

[85] T. Ergun, U. Ince, E. Ekşioğlu-Demiralp et al., "HSP 60 expression in mucocutaneous lesions of Behçet's disease," Journal of the American Academy of Dermatology, vol. 45, no. 6, pp. 904909, 2001.

[86] E. Deniz, U. Guc, N. Buyukbabani, and A. Gul, "HSP 60 expression in recurrent oral ulcerations of Behet's disease," Oral Surgery, Oral Medicine, Oral Pathology, Oral Radiology and Endodontology, vol. 110, no. 2, pp. 196-200, 2010.

[87] T. E. Bramanti, N. P. Dekker, F. Lozada-Nur, J. J. Sauk, and J. A. Regezi, "Heat shock (stress) proteins and $\gamma \delta$ T lymphocytes in oral lichen planus," Oral Surgery, Oral Medicine, Oral Pathology, Oral Radiology and, vol. 80, no. 6, pp. 698-704, 1995.

[88] K. Pervin, A. Childerstone, T. Shinnick et al., "T cell epitope expression of mycobacterial and homologous human 65- kilodalton heat shock protein peptides in short term cell lines from patients with Behcet's disease," The Journal of Immunology, vol. 151, no. 4, pp. 2273-2282, 1993.
[89] H. Direskeneli, E. Ekşioğlu-Demiralp, Ş. Yavuz et al., “T cell responses to $60 / 65 \mathrm{kDa}$ heat shock protein derived peptides in Turkish patients with Behcet's disease," Journal of Rheumatology, vol. 27, no. 3, pp. 708-713, 2000.

[90] S. Kaneko, N. Suzuki, N. Yamashita et al., "Characterization of T cells specific for an epitope of human $60-\mathrm{kD}$ heat shock protein (hsp) in patients with Behcet's disease (BD) in Japan," Clinical and Experimental Immunology, vol. 108, no. 2, pp. 204-212, 1997.

[91] J. Shimizu, T. Izumi, and N. Suzuki, "Aberrant activation of heat shock protein 60/65 reactive $\mathrm{T}$ cells in patients with Behcet's disease," Autoimmune Diseases, vol. 2012, Article ID 105205, 7 pages, 2012.

[92] W. W. Eaton, N. R. Rose, A. Kalaydjian, M. G. Pedersen, and P. B. Mortensen, "Epidemiology of autoimmune diseases in Denmark," Journal of Autoimmunity, vol. 29, no. 1, pp. 1-9, 2007.

[93] R. L. van Wanrooij, A. Zwiers, G. Kraal, and G. Bouma, "Genetic variations in interleukin-12 related genes in immune-mediated diseases," Journal of Autoimmunity, vol. 39, no. 4, pp. 359-368, 2012.

[94] R. H. Duerr, K. D. Taylor, S. R. Brant et al., "A genome-wide association study identifies IL23R as an inflammatory bowel disease gene," Science, vol. 314, no. 5804, pp. 1461-1463, 2006.

[95] R. P. Nair, K. C. Duffin, C. Helms et al., "Genome-wide scan reveals association of psoriasis with IL-23 and NF- $\kappa$ B pathways," Nature Genetics, vol. 41, no. 2, pp. 199-204, 2009.

[96] J. D. Reveille, A.-M. Sims, P. Danoy et al., "Genome-wide association study of ankylosing spondylitis identifies non-MHC susceptibility loci," Nature Genetics, vol. 42, no. 2, pp. 123-127, 2010.

[97] M. Chen-Xu, R. Topless, C. McKinney et al., "Replication of association of the interleukin 23 receptor rs1343151 variant with rheumatoid arthritis in Caucasian sample sets," Annals of the Rheumatic Diseases, vol. 71, no. 1, pp. 155-157, 2012.

[98] G. F. Mells, J. A. B. Floyd, K. I. Morley et al., "Genomewide association study identifies 12 new susceptibility loci for primary biliary cirrhosis," Nature Genetics, vol. 43, no. 4, pp. 332-333, 2011.

[99] T. Guo, S. Yang, N. Liu, S. Wang, B. Cui, and G. Ning, "Association study of interleukin-12A gene polymorphisms with Graves' disease in two Chinese populations," Clinical Endocrinology, vol. 74, no. 1, pp. 125-129, 2011.

[100] C. Núñez, B. Dema, M. C. Cénit et al., "IL23R: a susceptibility locus for celiac disease and multiple sclerosis?" Genes and Immunity, vol. 9, no. 4, pp. 289-293, 2008.

[101] S. Sawcer, G. Hellenthal, M. Pirinen et al., "Genetic risk and a primary role for cell-mediated immune mechanisms in multiple sclerosis," Nature, vol. 476, no. 7359, pp. 214-219, 2011.

[102] Y. Kirino, G. Bertsias, Y. Ishigatsubo et al., "Genome-wide association analysis identifies new susceptibility loci for Behçet's disease and epistasis between HLA-B* 51 and ERAP1," Nature Genetics, vol. 45, no. 2, pp. 202-207, 2013.

[103] E. F. Remmers, F. Cosan, Y. Kirino et al., "Genome-wide association study identifies variants in the MHC class I, IL10, and IL23R-IL12RB2 regions associated with Behçet's disease," Nature Genetics, vol. 42, no. 8, pp. 698-702, 2010.

[104] Y. Fei, R. Webb, B. L. Cobb, H. Direskeneli, G. SaruhanDireskeneli, and A. H. Sawalha, "Identification of novel genetic susceptibility loci for Behçet's disease using a genome-wide association study," Arthritis Research and Therapy, vol. 11, no. 3, article R66, 2009. 
[105] N. Mizuki, A. Meguro, M. Ota et al., "Genome-wide association studies identify IL23R-IL12RB2 and IL10 as Behçet's disease susceptibility loci," Nature Genetics, vol. 42, no. 8, pp. 703-706, 2010.

[106] A. Meguro, H. Inoko, M. Ota et al., "Genetics of Behçet disease inside and outside the MHC," Annals of the Rheumatic Diseases, vol. 69, no. 4, pp. 747-754, 2010.

[107] S. Hou, Z. Yang, L. Du et al., "Identification of a susceptibility locus in STAT4 for Behçet's disease in Han Chinese in a genome-wide association study," Arthritis and Rheumatism, vol. 64, no. 12, pp. 4104-4113, 2012.

[108] J. M. Xavier, F. Shahram, F. Davatchi et al., "Association study of IL10 and IL23R-IL12RB2 in Iranian patients with Behçet's disease," Arthritis and Rheumatism, vol. 64, no. 8, pp. 2761-2772, 2012.

[109] E. S. Kim, S. W. Kim, C. M. Moon et al., "Interactions between IL17A, IL23R, and STAT4 polymorphisms confer susceptibility to intestinal Behcet's disease in Korean population," Life Sciences, vol. 90, no. 19-20, pp. 740-746, 2012.

[110] M. de Menthon, M. P. Lavalley, C. Maldini, L. Guillevin, and A. Mahr, "HLA-B51/B5 and the risk of Behçet's disease: a systematic review and meta-analysis of case-control genetic association studies," Arthritis Care and Research, vol. 61, no. 10, pp. 1287-1296, 2009.

[111] S. Pestka, C. D. Krause, D. Sarkar, M. R. Walter, Y. Shi, and P. B. Fisher, "Interleukin-10 and related cytokines and receptors," Annual Review of Immunology, vol. 22, pp. 929-979, 2004.

[112] M. Fagerås Böttcher, M. Hmani-Aifa, A. Lindström et al., "A TLR4 polymorphism is associated with asthma and reduced lipopolysaccharide-induced interleukin-12(p70) responses in Swedish children," Journal of Allergy and Clinical Immunology, vol. 114, no. 3, pp. 561-567, 2004.

[113] C. Salpietro, L. Rigoli, M. Miraglia del Giudice et al., "TLR2 and TLR4 gene polymorphisms and atopic dermatitis in Italian children: a multicenter study," International Journal of Immunopathology and Pharmacology, vol. 24, no. 4, pp. 33-40, 2011.

[114] P. Ahmad-Nejad, S. Mrabet-Dahbi, K. Breuer et al., "The toll-like receptor 2 R753Q polymorphism defines a subgroup of patients with atopic dermatitis having severe phenotype," Journal of Allergy and Clinical Immunology, vol. 113, no. 3, pp. 565-567, 2004.

[115] M. Kerkhof, D. S. Postma, B. Brunekreef et al., "Toll-like receptor 2 and 4 genes influence susceptibility to adverse effects of traffic-related air pollution on childhood asthma," Thorax, vol. 65 , no. 8, pp. 690-697, 2010.

[116] K. G. E. Miedema, W. J. E. Tissing, E. M. te Poele et al., "Polymorphisms in the TLR6 gene associated with the inverse association between childhood acute lymphoblastic leukemia and atopic disease," Leukemia, vol. 26, no. 6, pp. 1203-1210, 2012.

[117] T. Sada, M. Ota, Y. Katsuyama et al., "Association analysis of toll-like receptor 7 gene polymorphisms and Behçet's disease in Japanese patients," Human Immunology, vol. 72, no. 3, pp. 269272, 2011.

[118] I. Ben Dhifallah, J. Lachheb, H. Houman, and K. Hamzaoui, "Toll-like-receptor gene polymorphisms in a Tunisian population with Behçet's disease," Clinical and Experimental Rheumatology, vol. 27, no. 2, supplement 53, pp. S58-S62, 2009.

[119] L. Boiardi, F. Atzeni, B. Casali et al., "Toll-like receptor 4 (TLR4) gene polymorphisms in Italian patients with Behçet's disease," Clinical and Experimental Rheumatology, vol. 27, no. 2, supplement 53, pp. S43-S47, 2009.
[120] F. Coşan, B. Oku, A. Cakiris et al., "No association of the TLR2 gene Arg753Gln polymorphism with rheumatic heart disease and Behçet's disease," Clinical Rheumatology, vol. 28, no. 12, pp. 1385-1388, 2009.

[121] R. Tomiyama, A. Meguro, M. Ota et al., "Investigation of the association between toll-like receptor 2 gene polymorphisms and Behçet's disease in Japanese patients," Human Immunology, vol. 70, no. 1, pp. 41-44, 2009.

[122] A. Meguro, M. Ota, Y. Katsuyama et al., "Association of the toll-like receptor 4 gene polymorphisms with Behçet's disease," Annals of the Rheumatic Diseases, vol. 67, no. 5, pp. 725-727, 2008.

[123] A. Ito, M. Ota, Y. Katsuyama, H. Inoko, S. Ohno, and N. Mizuki, "Lack of association of toll-like receptor 9 gene polymorphism with Behçet's disease in Japanese patients," Tissue Antigens, vol. 70, no. 5, pp. 423-426, 2007.

[124] A. Bacanli, N. Sallakci, U. Yavuzer, E. Alpsoy, and O. Yegin, "Toll-like receptor 2 Arg753Gln gene polymorphism in Turkish patients with Behçet's disease," Clinical and Experimental Dermatology, vol. 31, no. 5, pp. 699-701, 2006.

[125] Y. Kirino, Q. Zhou, Y. Ishigatsubo et al., “Targeted resequencing implicates the familial Mediterranean fever gene MEFV and the toll-like receptor 4 gene TLR4 in Behçet disease," Proceedings of the National Academy of Sciences of the United States of America, vol. 110, no. 20, pp. 8134-8139, 2013.

[126] P. P. Sfikakis, N. Markomichelakis, E. Alpsoy et al., "Anti-TNF therapy in the management of Behçet's disease-review and basis for recommendations," Rheumatology, vol. 46, no. 5, pp. 736-741, 2007.

[127] H. Ideguchi, A. Suda, M. Takeno et al., "Gastrointestinal manifestations of Behçet's disease in Japan: a study of 43 patients," Rheumatology International, 2013.

[128] J. Chen, J. Ren, G. Gu et al., "Crohn's disease and polymorphism of heat shock protein gene HSP70-2 in the Chinese population," Journal of Gastroenterology and Hepatology, vol. 28, no. 5, pp. 814-818, 2013.

[129] S. M. Davis, E. A. S. Clark, L. T. Nelson, and R. M. Silver, “The association of innate immune response gene polymorphisms and puerperal group A streptococcal sepsis," American Journal of Obstetrics and Gynecology, vol. 202, no. 3, pp. 308.e1-308.e8, 2010.

[130] Y. Zhao, L. Tao, D. Jiang et al., "The -144C/A polymorphism in the promoter of HSP90beta is associated with multiple organ dysfunction scores," PLoS ONE, vol. 8, no. 3, Article ID e58646, 2013. 



Submit your manuscripts at

http://www.hindawi.com

Journal of
Signal Transduction
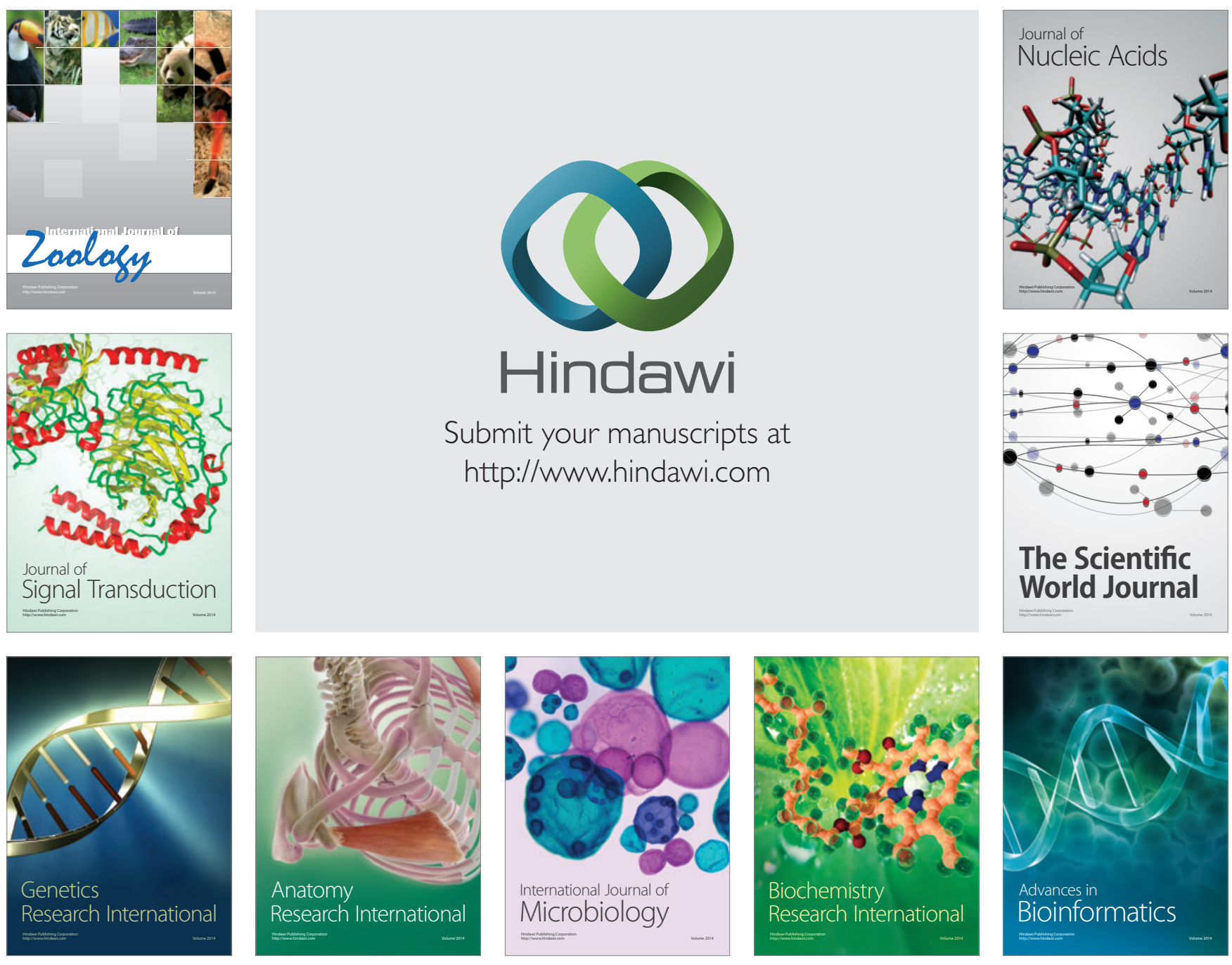

The Scientific World Journal
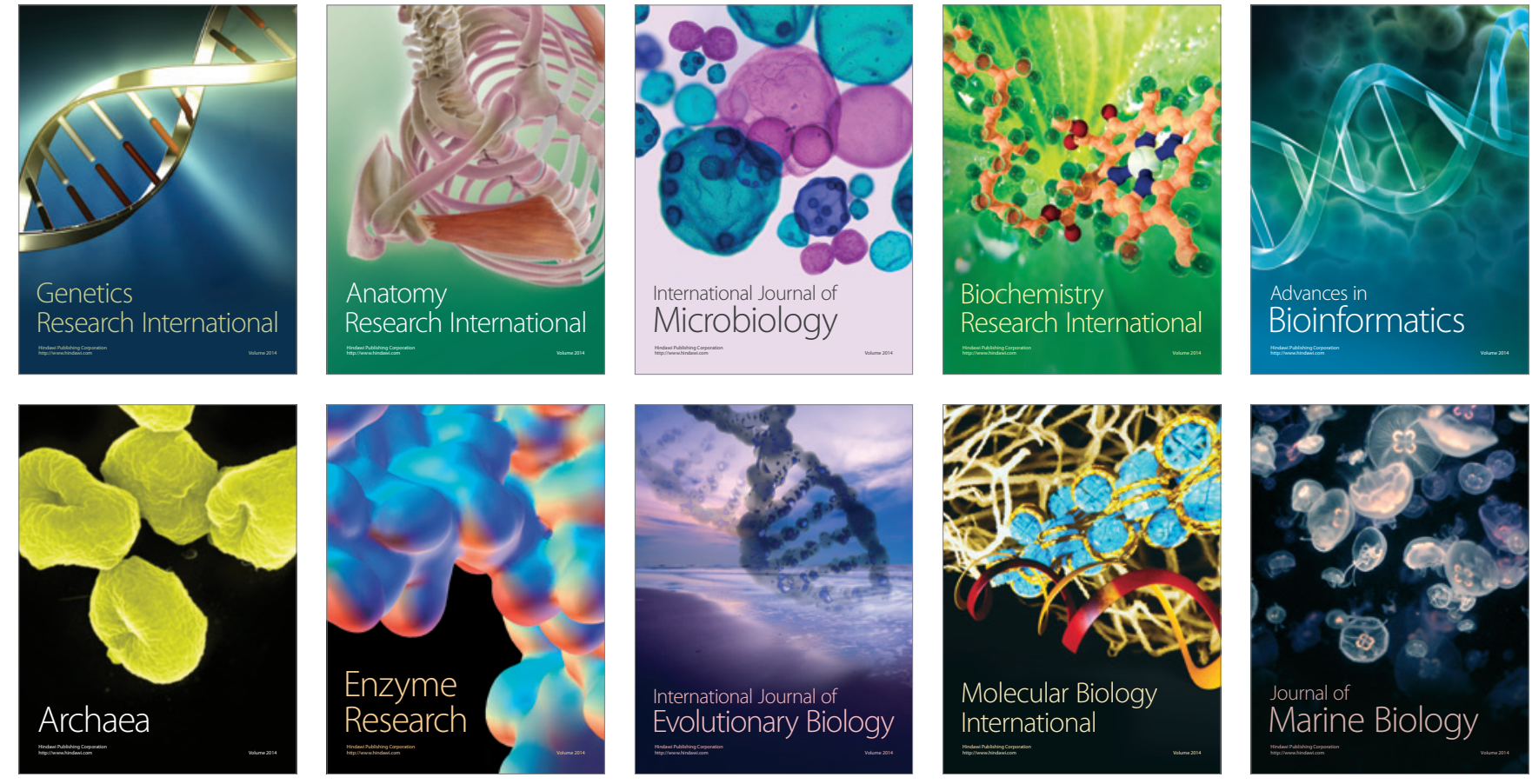